JACEK RUDEWICZ

Uniwersytet Szczeciński, Polska - The University of Szczecin, Szczecin, Poland

KrzYSZTOF SALA

Uniwersytet Pedagogiczny w Krakowie, Polska - Pedagogical University of Krakow, Poland

\title{
Szczecin i Berlin - zarys wzajemnych relacji pomiędzy miastami
}

\section{Szczecin (Poland) and Berlin (Germany) - outline of mutual relations between cities}

Streszczenie: Autorzy artykułu za główny cel przyjęli ukazanie obecnego kształtu wzajemnych relacji pomiędzy dwoma miastami, które łączyła w przeszłości przynależność państwowa (Republika Weimarska, Rzesza Niemiecka). Zależności te to szeroko rozumiana wymiana gospodarcza i dyfuzja społeczno-kulturowa. Zestawiono ze sobą dwa miasta o różnej pozycji w hierarchii osadniczej i sile oddziaływania. Berlin, znacznie większy ośrodek miejski pełniący funkcje stołeczne wiodącego gospodarczo państwa w Europie, obszar metropolitalny, miasto/region o statucie kraju związkowego, oraz Szczecin (Stettin) niegdyś stolica prowincji Pommern, obecnie województwa zachodniopomorskiego. Miasto o funkcjach portowych, przemysłowych i regionalnych funkcjach administracyjnych oraz rozwijających się usługach. Dla realizacji tego celu posłużono się podejściem retrospekcyjnym, którego zadaniem jest projekcja minionych możliwych do odbudowania w pewnym zakresie ograniczonych współczesnymi uwarunkowaniami więzi obu miast. W obecnej sytuacji geopolitycznej i obecnym klimacie gospodarczym, pomimo że miasta te znajdują się w innych układach osadniczych dwóch państw, ich przynależność państwowa nie powinna stanowić istotnej przeszkody do czerpania wzajemnych korzyści ze swojej relatywnej przestrzennej bliskości (ok. $150 \mathrm{~km}$ ). Bliskość ma też wymiar polityczny, wynika ze wspólnej przynależności Niemiec i Polski m.in. do Unii Europejskiej i strefy Schengen, wspólnego rynku, tych samych organizacji gospodarczych, społecznych i geostrategicznych (NATO). $\mathrm{Na}$ tle zmian politycznych usuwających bariery i skracających drogę w wymiarze politycznym i prawnym do wzmocnienia wzajemnych relacji między miastami wyraźne stały się potrzeby infrastrukturalne pokonujące opór przestrzeni. Nie bez znaczenia są również potrzeby podjęcia obopólnych wysiłków polsko-niemieckich zmierzających do zniesienia barier mentalnych i organizacyjnych w czerpaniu korzyści z bliskości położenia. Motywem wyboru tematyki publikacji były osobiste zainteresowania naukowe autorów, jak również ograniczona liczba publikacji dotycząca omawianego obszaru, zwłaszcza z najnowszego okresu. Artykuł ma charakter deskryptywny, powstał przy wykorzystaniu przeglądu literatury, materiałów prasowych oraz informacji netograficznych. Metodę badawczą zastosowaną w publikacji stanowi analiza danych zastanych i krytyka piśmiennicza oraz elementy analizy porównawczej. Teza badawcza opiera się na stwierdzeniu, że stworzenie warunków do zacieśnienia współpracy Berlina ze Szczecinem daje obu miastom szansę na powstanie wielu wzajemnych korzyści gospodarczych i społecznych. 
Abstract: The main goal the article is the search for mutual relations between two cities, which in the past were united by nationality (Weimar Republic, German Reich), socio-economic and cultural dependence despite their different place in the settlement hierarchy. Berlin (Germany) as a much larger urban centre with broadly understood capital and metropolitan functions, and Szczecin (Stettin), once the capital of the Pommern province and currently of the Zachodniopomorskie Voivodeship, a city with port, service, industrial and administrative functions. To achieve this goal, a retrospective was used, its task is to project the ties between the two cities that can be rebuilt. In the current geopolitical situation and economic climate, despite the fact that these cities are located in different settlement systems of two countries, their nationality should not constitute a significant obstacle to reaping mutual benefits from their relative spatial proximity (about $150 \mathrm{~km}$ ). This closeness results from the common affiliation of Germany and Poland, among others to the common area of the European Union and the Schengen zone, political, economic, social and geostrategic projects. In addition to political changes that open up and shorten the path to strengthening mutual relations between cities, there are also infrastructural needs that overcome the resistance of space between cities, as well as efforts to remove mental and organisational barriers. The choice of the subject of the publication was based on the personal scientific interests of both authors, as well as a limited amount of literature on the subject, especially from the most recent period.The article was created with the use of book materials, magazines, as well as netographic information. The research method used in the publication is the analysis of existing data and literary criticism. The research thesis is based on the statement that cooperation between Berlin and Szczecin may contribute to many positive socio-economic results. The research results positively verify the thesis.

Słowa kluczowe: ekonomia; Niemcy; Polska; społeczeństwo; współpraca

Keywords: cooperation; economy; Germany; Poland; society

Otrzymano: 23 października 2021

Received: 23 October 2021

Zaakceptowano: 5 grudnia 2021

Accepted: 5 December 2021

\section{Sugerowana cytacja/Suggested citation:}

Rudewicz, J., Sala, K. (2021). Szczecin i Berlin - zarys wzajemnych relacji pomiędzy miastami. Przedsiębiorczość - Edukacja [Entrepreneurship - Education], 17(2), 164-180. https://doi. org/10.24917/20833296.172.12

\section{Wstęp}

Celem niniejszego artykułu jest określenie i poznanie wzajemnych relacji społeczno-kulturowych i gospodarczych zachodzących pomiędzy Berlinem a Szczecinem. Opracowanie poświęcone badaniu wzajemnych relacji dwóch miast stanowi wyzwanie metodologiczne i koncepcyjne, zwłaszcza w odniesieniu do miast o różnej randze w hierarchii osadniczej. Miast niegdyś połączonych więzami wspólnej państwowości, od 1945 r. pozostających w innych strukturach państwowych, a od pewnego czasu połączonych wspólnym mianownikiem agregacji polityczno-gospodarczej Unii Europejskiej i strefy Schengen. Wspomniana trudność wymaga określenia płaszczyzn wzajemnych relacji oraz zdefiniowania samego pojęcia relacji miast. Doprecyzowania wymaga również moment, w którym rzeczone relacje są analizowane. Pojawia się tu problem określenia zasięgu oddziaływania przestrzennego ośrodków oraz nakładających się na te relacje wielu kontekstów - od polityki rozwoju regionalnego i transgranicznych działań lokalnych, poprzez współpracę międzynarodową na poziomie krajowym, do polityki Unii Europejskiej względem współpracy transgranicznej. 
W analizie relacji wzajemnych miast uściślić należy, co rozumiane jest pod pojęciem miasta, gdyż dzisiejsze pojęcie i rozumienie miasta przenosi się poza jego granice administracyjne na teren jego oddziaływania funkcjonalnego, zasięg mniej lub bardziej sformalizowanego organizacyjnie obszaru metropolitalnego, regionu miejskiego czy też rozmytych granic dziennego systemu miejskiego. W przypadku miast o wyższej radze w układzie osadniczym właściwym jest rozpatrywanie relacji pomiędzy tworzonymi przez nie trudnymi do delimitacji strefami bezpośredniego wpływu na otoczenie. Ranga rozumiana w zgodzie z teorią Christallera (Nowosielska, 1992) wyposaża miasta w wiele kompetencji administracyjnych, gospodarczych, kulturowych, nadaje im impet rozwojowy. Stąd analiza relacji powinna uwzględniać założenia koncepcji biegunów wzrostu i polaryzacji rozwoju (Grzeszczak, 1999). Biegunów posiadających swoje pole grawitacji o odpowiednim zasięgu. W rozważaniach o mieście większym i dominującym pojawia się pojęcie miast satelitarnych, siły pozytywnego i negatywnego oddziaływania miasta centralnego na satelity. Zależności mierzonej przepływami towarów i osób, migracji, liczby kooperujących podmiotów gospodarczych, generowanych miejsc pracy, liczby pełnionych funkcji uzupełniających. Do takich funkcji należeć mogą funkcje rezydencjalne, obronne, przemysłowe, transportowe, turystyczne i rekreacyjne.

Do zagadnienia analizy relacji miast można podejść w sposób metaforyczny poprzez porównanie konstrukcji badania do układu planetarnego, orbity, grawitacji, przyciągania, bez utraty liczbowego i parametrycznego charakteru tych badań. Metafora dotyczyć może analizy wzajemnych relacji w myśl podejścia organicystycznego, porównującego miasta niezależne byty - do organizmów wymieniających materię i masę, żyjących w symbiozie lub konkurencji (w nawiązaniu do teorii ekologii miasta). Tutaj też pojawia się spojrzenie na problem przez pryzmat ekonomii, w którym miasta poprzez analogię do przedsiębiorstw lub organizacji konkurują lub współpracują ze swoim otoczeniem, przenoszą egzogeniczne i terenochłonne funkcje gospodarcze na zewnątrz - teoria bazy ekonomicznej miast (Dziewoński, 1967). Pogłębiając analizę ekonomiczną, można użyć analogii rachunkowych na podstawie bilansu wzajemnych zysków i strat wynikających z oddziaływania miast na siebie. Współcześnie pomimo rozwoju gospodarki cyfrowej, w pewnym stopniu aprzestrzennej, nadal istotne znaczenie ma bliskość w wymiarze geograficznym, która stanowi rodzaj funkcji efektów oporu czasu i przestrzeni. Płaszczyzna wzajemnych relacji miast to pojęcie wielowymiarowe, podstawą jest $\mathrm{w}$ niej dowiązanie przestrzenne jednostki lub podmiotu gospodarczego w jednym z porównywanych obszarów. Mowa zatem o płaszczyźnie fizycznej, w której dochodzi do przemieszczenia czasowego osób, podmiotów gospodarczych, podążającym za tym strumieniem towarów i usług. To płaszczyzna prowadząca do powstania zjawiska turystyki, czasowej (wahadłowej) migracji do miejsc pracy, zmiany miejsca zamieszkania lub trwałej migracji działalności gospodarczej, budowanie zasięgu rynku zbytu i świadczenia usług w oparciu o dwa terytoria. Za tą płaszczyzną postępują wpływ kulturowy, relatywnie trudniejszy w diagnozie, oraz kwestie obopólnego postrzegania, wizerunku danego miasta przez mieszkańców drugiego miasta i opinie płynące z kręgów gospodarczych. Tutaj ważna jest nośność wizerunkowa tego postrzegania, np. w zakresie atrakcyjności turystycznej, zakupowej, wydarzeń masowych, a także możliwości i ryzyka prowadzenia działalności gospodarczej, rynku zbytu. Innym trybem wzajemnych relacji jest działanie wspólne, solidarne - jawny lub kontekstowy sojusz miast względem pojawiających się zmian w otoczeniu lub też kwestie wzajemnych wysiłków miast skierowanych do zacieśnienia współpracy. 
Warto również zwrócić uwagę na wpływ na badane dwa miasta i szeroko rozumiane relacje między nimi miast trzecich, które mogą konkurować, przejmować, budować relacje konkurencyjne. Nie musi być to miasto najbliższe geograficznie i dostępne komunikacyjne; na charakter relacji wpływa ranga. Berlin i Warszawa są stolicami państw, a Szczecin z racji państwowej przynależności łączy z Warszawą więź administracyjna, biznesowa i kulturowa. Nie można jednak zapomnieć o fakcie, że przed 1945 r. to Berlin pełnił funkcje stołeczne dla Szczecina. Z racji portowego charakteru miasta ówczesny Stettin pełnił funkcje bramowe dla Berlina głównie w relacjach bałtyckich. Współcześnie wydaje się, i mówią o tym fakty, że jest odwrotnie - bramą dla Szczecina jest Berlin poprzez efekt skali jego portów lotniczych. Z powyższych rozważań wyłania się obraz skomplikowanego, wielowymiarowego obszaru badawczego.

\section{Retrospekcja historyczna korzeni i ewolucji współpracy Berlina ze Szczecinem}

Dla precyzyjnego scharakteryzowania ewolucji współpracy Berlina ze Szczecinem należy wyróżnić trzy okresy wzajemnych kontaktów obu miast. Pierwszy okres można wyznaczyć od 1285 r. (przynależność Szczecina, stolicy Księstwa Pomorskiego, do Hanzy) tuż po tym, jak w 1243 r. miasto uzyskało prawa miejskie do roku 1945. W tym przedziale czasu istotny jest podokres od XVIII w. do ostatnich miesięcy drugiej wojny światowej, kiedy oba miasta znajdowały się (z niewielkimi przerwami) na terenie jednego organizmu państwowego (Niemiec). Kolejny okres można wyznaczyć od 5 lipca 1945 r. do przełomu lat 1989/1990, kiedy Szczecin został włączony do granic państwa polskiego (PRL) (Łysakowska, 2015). Z kolei Berlin został podzielony na część wschodnią przynależną radzieckiej strefie wpływów (NRD) i zachodnią znajdującą się pod kontrolą RFN i aliantów. Podzielone granicami miasta ograniczyły charakter swojej dotychczasowej współpracy. Działo się tak nawet w okresie wspólnej przynależności NRD i PRL do bloku wschodniego i Układu Warszawskiego. W trzydziestoletnim okresie od 1989 r. - początków transformacji ustrojowej i zjednoczenia Niemiec - do współczesności szczególnym momentem jest 1 maja 2004 r., formalna data uzyskania przez Polskę statusu członka Unii Europejskiej, a następnie 21 grudnia 2007 r. - wejście Polski do strefy Schengen.

W wymienionych okresach intensyfikacja współpracy Belina ze Szczecinem przypadła na czas po 1720 r. Szczecin bowiem jako stolica autonomicznego Księstwa Pomorskiego wraz z całą prowincją Pommern został włączony do Prus i Rzeszy. Z perspektywy Berlina zaczął odgrywać większą rolę niż wcześniej (Białecki, 1992). Zaczął być wymieniany jako drugi największy niemiecki port (po Hamburgu, który obsługiwał połączenia transatlantyckie) i kluczowa brama na Bałtyk (fotografia 1). Przez Szczecin importowano do Berlina i innych miast Niemiec takie surowce, jak zboże z Rosji (później ze Związku Radzieckiego) czy rudy metali ze Skandynawii. Natomiast eksportowano cement i towary drobnicowe. Miasto było ogniwem w łańcuchu dostaw i transporcie osobowym, ośrodkiem przemysłowym w produkcji stoczniowej (Mąka, 1978).

Znaczenie gospodarcze, tranzytowe, powodowało, że wydarzenia polityczne w Berlinie stosunkowo szybko odbijały się echem także w Szczecinie. Przykładem mogą być np. zamieszki ziemniaczane - początki buntu robotniczego i demokratyzacji Niemiec w połowie XIX w. W Szczecinie miały miejsce podobne wydarzenia.

Pod wpływem promieniowania twórczego Berlina znajdowały się również szczecińska kultura i architektura. Wielu twórców szczecińskich studiowało w Berlinie na Akademii 
Fotografia 1. Materiały promocyjne Szczecina z lat 30. XX w.

a)

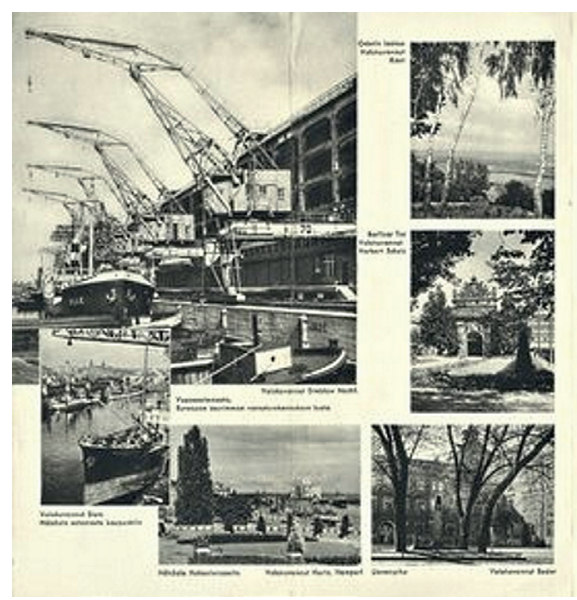

b)

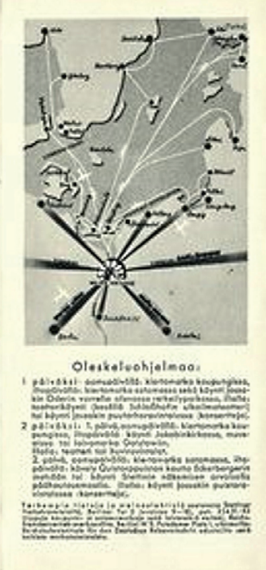



Źródło: a) Omnia. Repozytorium Cyfrowe Instytutów Naukowych; b) Christies (https://www.christies.com/lot/ anonymous-stettin-4558829/?intObjectID=4558829\&lid=1)

Sztuki, w tym Ludwig Manzel - twórca Manzel Brunnen (Sediny) (Hahn, 2007). Warto wspomnieć również o postaci Jamesa Hobrechta. Ten wybitny inżynier niemiecki zaprojektował i uruchomił zakłady wodociągowe oraz system kanalizacji dla obu miast. Był także twórcą planów urbanistycznych dużej części obu ośrodków. Mieszkał i pełnił swe funkcje zarówno w Szczecinie, jak i w Berlinie (Strohmeyer, 2000). Wyrazem podobieństw obu miast na płaszczyźnie architektury jest obecność w obu jako jedynych w Europie czerwonych ratuszy, eklektycznych kamienic, gmachów zaprojektowanych często przez tych samych architektów. Szczecińskie elity kształciły się lub inicjowały swoje kariery poprzez naukę, praktykę i kontakty z uczelniami i środowiskiem twórczym w Berlinie. Tworzyli je znani aktorzy urodzeni w Stettinie przed II wojną światową, np. Heinrich George (dyrektor teatru im. Schillera w Berlinie), Eva Liebenberg, Dita Parlo (Gerda Olga Justina Kornstadt), Hans Heinrich von Twardowski, Erwin Bootz, Arnim Dahl, Hilde Weissner; słynni sportowcy, np. olimpijczyk Otto Peltzer, zapaśnik Werner Seelenbinder; twórcy tacy jak Heinz von Cramer; naukowcy, w tym Karl Ludwig Schleich - niemiecki chirurg, malarz, poeta. Przykładów ścieżek kariery wiodących przez Berlin jest znacznie więcej, część z osób kształcących się w ówczesnej stolicy powracała do miasta. Nie bez znaczenia jest fakt, że Stettin nie posiadał rozbudowanego szkolnictwa wyższego pomimo stosunkowo dużej liczby mieszkańców i świetnego szkolnictwa technicznego i średniego. Pierwszy uniwersytet powstał w mieście w 1984 r. z połączenia Wydziału Inżynieryjno-Ekonomicznego Transportu Politechniki Szczecińskiej oraz Wyższej Szkoły Pedagogicznej. Oddziaływanie uczelni berlińskich zarówno w kształceniu uniwersyteckim, jak i artystycznym mogło być bezpośrednią przyczyną trudności wpływających na nierozwinięcie się tego szczebla edukacji w Stettinie. Pewnego rodzaju drenaż talentów ma też miejsce współcześnie, bowiem miasto może poszczycić się najlepszym liceum ogólnokształcącym w kraju (XIII LO), a stosunkowo młode uczelnie wyższe w mieście dopiero budują swoją rangę.

Kolejny ważny okres wzajemnej współzależności przypadł na lata 30. XX w., kiedy władzę w Niemczech przejęli naziści. Nazizm w prowincji Pommern i Prusach Wschodnich 
zdobył duże poparcie mieszkańców. Ówczesna władza jeszcze bardziej podkreślała gospodarcze i strategiczne znaczenie miasta, czego wyrazem była wizyta Hitlera w Stettinie w 1938 r. (Rudnicki, 2010). Hitlerowskie Niemcy miały wobec miasta daleko idące plany rozbudowy i wzmocnienia jego potencjału, traktując je jako ważne miasto satelickie Berlina, ważny ośrodek przemysłowy i zbrojeniowy, czego dowodem są plany rozbudowy portu i przemysłu (Wojtkun, 2020). W październiku 1939 r. Stettin stał się Großstadt Stettin, granice miasta poszerzono o okoliczne wsie i miasteczka, celem wzmocnienia administracyjnego miasta wobec nadchodzących działań wojennych.

W wyniku powojennych zmian granic i porządków dyktowanych przez zwycięskie mocarstwa w Europie Szczecin stał się częścią Polski (Kozłowski, Krzywicki, 1988). W 1946 r. Winston Churchill wypowiedział znamienne słowa „Od Szczecina nad Bałtykiem do Triestu nad Adriatykiem żelazna kurtyna opuściła się na kontynent” (Wright, 2009). Miasto zostało pozbawione swojego funkcjonalnego zaplecza po zachodniej stronie - odcięto jedno jego skrzydło (lub płuco - jak mówili niektórzy). Szczecin jak każde miasto relatywnie dużej wielkości posiadał własny zasięg oddziaływania, egzogeniczny zasięg relacji z otoczeniem poprzez powiązania gospodarcze, istniejące zaplecze portu (hinterland), zasięg administracyjny, w tym kontakty z Berlinem, a także całym obszarem Brandenburgii i Meklemburgii - Pomorza Przedniego, poniekąd Gdańska i Królewca. Zerwanie zostały więzi gospodarcze, społeczne, polityczne, a nawet połączenia komunikacyjne pomiędzy Berlinem a Szczecinem. Granica między PRL a ówczesnym NRD, pomimo podobnego ustroju obu państw, stała się barierą na wiele lat. Warto tutaj wspomnieć, że szczeciński port od maja 1945 r. do września 1947 r. odgrywał kluczową rolę w przeładunku wywożonego z terenu Niemiec, zwłaszcza z Berlina, radzieckich łupów wojennych (Jesswein, 2019).

Od lat 90. XX w. sytuacja ta uległa zmianie. Powoli zaczęła się zarysowywać możliwość wznowienia współpracy Szczecina z Berlinem, a także innymi częściami Niemiec, w ramach współpracy sąsiedzkiej. Od 1996 r. Szczecin i Berlin pozostają we współpracy w ramach miast partnerskich. Wspomniana współpraca ma ożywić wymianę kulturalną, gospodarczą oraz informacyjną (Miasta partnerskie Miasta Szczecin, 2021, 2 czerwca), a także wprowadzić wzajemne relacje na zupełnie inny poziom. Od 2006 r. oba miasta, a także cztery regiony przygraniczne z obu państw, zainicjowały współpracę w ramach Partnerstwa Odry. Partnerstwo Odry ma służyć dalszemu pogłębieniu powiązań politycznych, gospodarczych i infrastrukturalnych między sąsiadującymi regionami (Bednarek, 2010).

\section{Gospodarcze aspekty współpracy Berlina ze Szczecinem}

W celu dokładnego omówienia gospodarczych aspektów współpracy Berlina ze Szczecinem należy zacząć od porównania kluczowych wskaźników gospodarczych obu metropolii i wzajemnych gospodarczych ciążeń. Kluczowe wskaźniki dla obu miast zaprezentowano w tabeli 1.

Dane zawarte w tabeli 1 wskazują wyraźnie, że Berlin w porównaniu ze Szczecinem wykazuje przewagę w zakresie wskaźników demograficznych i poziomu osiąganych dochodów. Wyższą stopę bezrobocia w Berlinie można tłumaczyć m.in. obecnością dużej liczby osób bezdomnych w mieście, niepracujących, a utrzymujących się z pomocy socjalnej (Widzyk, 2020). Siłę wzajemnych odziaływań Berlina i Szczecina (i innych miast) przedstawiono w tabeli 2 . Zawiera ona dane dotyczące ciążeń grawitacyjnych - metody 
analizy geograficznej. Metoda ta polega w zarysie na iloczynie mas np. liczby ludności lub PKB podzielonego przez najmniejszą odległość transportową. Wymiana dóbr pomiędzy dwoma miastami będzie odwrotnie proporcjonalna do łączącej je odległości (więcej: Chojnicki, 1965).

Tabela 1. Wybrane wskaźniki społeczno-gospodarcze Berlina i Szczecina w 2020 r.

\begin{tabular}{|l|c|c|}
\hline \multicolumn{1}{|c|}{ Wskaźnik } & Berlin & Szczecin \\
\hline Powierzchnia miasta w km ${ }^{2}$ & 891,69 & 301,30 \\
\hline Liczba ludności w tys. & 3664,088 & 398,255 \\
\hline Liczba ludności w aglomeracji w tys. & 6144,600 & 777,000 \\
\hline Gęstość zaludnienia na km² ${ }^{2}$ & 4108 & 1322 \\
\hline Przeciętne miesięczne wynagrodzenie w euro & 3242 & 1181 \\
\hline PKB per capita w euro & 41,967 & 11,827 \\
\hline Stopa bezrobocia w \% & 9,4 & 3,7 \\
\hline HDI (Human Development Index) & 0,95 & 0,85 \\
\hline Lasy i grunty leśne w \% & 18,4 & 16,9 \\
\hline
\end{tabular}

Źródło: Opracowanie własne na podstawie danych GUS i Amt für Statistik Berlin-Brandenburg

Tabela 2. Porównanie siły potencjalnych ciążeń pomiędzy najważniejszymi aglomeracjami w Polsce zachodniej z wybranymi miastami zagranicznymi

\begin{tabular}{|l|c|c|c|}
\hline \multicolumn{1}{|c|}{ Miasto/Miasto } & Poznań & Szczecin & Wroclaw \\
\hline Poznań & - & 8,5 & 19,7 \\
\hline Szczecin & 8,5 & - & 3,3 \\
\hline Wrocław & 19,7 & 3,3 & - \\
\hline Warszawa & 18,4 & 5,5 & 15,5 \\
\hline Katowice & 21,1 & 5,9 & 56,7 \\
\hline Berlin & 45,4 & 126,0 & 29,1 \\
\hline Praga & 9,5 & 5,2 & 19,2 \\
\hline
\end{tabular}

Źródło: Śleszyński (2009)

Analiza danych zawartych w tabeli 2 pozwala stwierdzić, że w ujawnionym zestawieniu Szczecin i Berlin wykazują się wysokim poziomem potencjalnej siły wzajemnego ciążenia gospodarczego, co będzie rodziło określone konsekwencje dla obu ośrodków w przyszłości. Zdaniem Śleszyńskiego (2009), kierunki ciążeń, wynikające również z potencjału ludnościowego, powinny być przesłanką do planów budowy dróg ekspresowych i autostrad.

Istotnym elementem ułatwiającym zacieśnianie wspólnych więzi gospodarczych są połączenia komunikacyjne. Szczecin i Świnoujście dla obszaru Berlina i Brandenburgii stanowią naturalne i jednocześnie najbliższe geograficznie ogniowo w połączeniach komunikacyjnych z Morzem Bałtyckim. Zatem istotną rolę w intensyfikacji powiązań odgrywać będzie kondycja ekonomiczna i wymiana handlowa ze Skandynawią, państwami bałtyckimi i Rosją. Z kolei Berlin jako duży ośrodek miejski i węzeł logistyczny jest istotnym odbiorcą i jednocześnie pośrednikiem w ruchu towarów przeładowywanych w szczecińskim porcie. Do tego należy dodać Berlin jako odbiorcę produktów wytwarzanych na terenie Szczecina i okolic (Frymus, 2021, 3 lipca). 
Odległość drogowa pomiędzy miastami wynosi nieco ponad $150 \mathrm{~km}$ (rycina 1), co wydatnie ułatwia wzajemne kontakty. Szczecin jest najbliżej położonym od Berlina dużym (ok. 400 tys. mieszkańców) miastem. Dla porównania: Szczecin i Warszawę dzieli ponad $550 \mathrm{~km}$.

Wyrazem znaczenia wzajemnych powiązań Szczecina z Berlinem było kilka ważnych inwestycji transportowych, których początek datuje się już na XVII w. Z racji położenia obu miast wzdłuż przebiegu rzek w pierwszej kolejności należy wymienić transport wodny. Ważnym wydarzeniem w tym zakresie było wybudowanie już w 1605 r. kanału Finow. Ta licząca $32 \mathrm{~km}$ arteria wodna umożliwiła wygodne połączenie Haweli i Odry. Gospodarcze znaczenie tego kanału polegało na transporcie surowców w obu kierunkach. Berlińska odlewnia żelaza Budde \& Goehde pozyskiwała rudę żelaza oraz koks z Anglii i Luksemburga poprzez szczeciński port. Z kolei w przeciwnym kierunku były transportowane towary na tereny Saksonii poprzez Berlin (Uhlemann, 1994). W 1891 r. powstało kolejne, alternatywne połączenie wodne Berlina ze Szczecinem: kanał Odra - Sprewa, który umożliwiał uniezależnienie transportu wodnego obu miast od wcześniej istniejących połączeń (Starcken, 2016).

Ważnym wydarzeniem w historii połączeń wodnych Berlina ze Szczecinem było otwarcie w 1914 r. nowoczesnego kanału wodnego Odra - Havela (Strączyński, 2019). Omawiany kanał zastąpił w użyciu funkcjonujący wcześniej kanał Finow. Dla podkreślenia istotnego znaczenia tego toru wodnego dla relacji Berlina ze Szczecinem warto dodać, że pierwotna nazwa tej inwestycji miała brzmieć Grossschifffahrtweg Berlin-Stettin (Droga Wodna Berlin - Szczecin). Kanał Odra - Havela ze względu na swoje nowoczesne parametry techniczne umożliwiał szybsze przemieszczanie się większych jednostek pływających. Całkowita długość drogi wodnej Havela - Odra (niem. Havel-Oder-Wasserstraße HOW) wynosi 101,6 km.

Wyrazem rosnącego znaczenia omawianego kanału są obecne prace nad nową i jednocześnie największą podnośnią kanałową na świecie w Niederfinow. Oddanie jej do użytku wydatnie usprawni przepustowość kanału i zwiększy wymianę handlową pomiędzy Szczecinem a Berlinem (Madejski, 2018) (fotografia 2). Kanał Odra - Havela współcześnie największą rolę w transporcie wodnym pomiędzy Polską a Niemcami, a także poprzez inne kanały z innymi krajami Europy Zachodniej. Wzdłuż drogi wodnej Szczecin - Berlin znajduje się kilkanaście portów i przystani śródlądowych. Najwięcej z nich zlokalizowanych jest w Berlinie i okolicy. Większość z wymienionych portów wyposażonych jest w bocznicę kolejową i dostęp do autostrad przechodzących przez Okręg Berliński (Kotowska, 2011). W strukturze transportu cargo pomiędzy miastami dominują obecnie drobnica, zboże oraz węgiel.

Warunkiem dalszej aktywizacji omawianej drogi wodnej i jej wydatniejszego wykorzystania będzie intensyfikacja powiązań handlowych pomiędzy uczestnikami rynku zlokalizowanymi wzdłuż drogi wodnej Szczecin - Berlin. Nie bez znaczenia byłoby wykorzystanie tutaj na większą skalę tranzytowego portu w Schwedt. Ponadto istotnym byłoby stworzenie kompleksowej i konkurencyjnej oferty handlowej obejmującej przewozy drogą wodną, utworzenie regularnych połączeń kontenerowych konkurencyjnych pod względem ceny i czasu przewozu pomiędzy portami będącymi hubami kontenerowymi, oraz aktywną promocję nowych usług przewozowych. Warto również wspomnieć o rozwoju turystyki wodnej, która w Niemczech ma ok. 6 mln uczestników (z tego 200 tys. w rejonie Brandenburgia - Berlin), a w samym Berlinie jest około 23300 łodzi motorowych (Zbroja, 2021, 30 sierpnia). 
Fotografia 2. Nowoczesna śluza Finow



Źródło: https://upload.wikimedia.org/wikipedia/commons/thumb/1/1f/17-05-23-Fotoflug_Barnim-a_RR70818. jpg/1280px-17-05-23-Fotoflug_Barnim-a_RR70818.jpgw

Warto również wspomnieć o połączeniach kolejowych. Od 1843 r. Szczecin jako miasto otrzymał połączenie kolejowe z Berlinem, co dało początek kolei na Pomorzu. Na szczeciński dworzec o nazwie Berliner Bahnhof, czyli Dworzec Berliński, pierwszy pociąg wjechał 15 sierpnia 1843 r. Kilka lat później wzdłuż linii kolejowej rozciągnięto kable telegrafu. W roku 1876 otwarto nowo wybudowany efektowny Dworzec Szczeciński w Berlinie (Stettiner Bahnhof), który na trwale zapisał się w historii miasta. Na podkreślenie zasługuje nazewnictwo dworców - Stettiner Bahnhoff w Berlinie i Berliner Bahnhoff w Stettinie. Linię włączono w sieć kolejową, a w 1924 rozpoczęto jej elektryfikację, co świadczy o randze połączenia. Linia ma 132,4 km długości. Oprócz przewozów towarowych dworzec pełnił również funkcję ważnego punktu startowego do nadmorskich kurortów (Lejman, 2020).

Po II wojnie światowej linia straciła na swoim znaczeniu. Związek Radziecki częściowo rozebrał te trasę - usunięto jeden tor i sieć trakcyjną na odcinku $40 \mathrm{~km}$. Stąd konieczna stała się przesiadka w drodze do Berlina w miejscowości Angermünde. Na początku XXI w. przedstawiono plany unowocześnienia linii na całej długości w celu podniesienia jej prędkości do $160 \mathrm{~km} / \mathrm{h}$. Jak na razie plany te nie zostały zrealizowane (Ferrix, 2021, 25 czerwca). Uciążliwe przesiadki i przerwy w podróży nie sprzyjają wzrostowi popularności kolei na tym odcinku. Szybkie połączenie kolejowe między oboma miastami mogłoby się przyczynić do wzrostu wymiany handlowej oraz ruchu turystycznego z korzyścią dla środowiska naturalnego. Byłoby też istotną alternatywą dla transportu drogowego.

Dla pełnego zobrazowania połączeń komunikacyjnych obu ośrodków miejskich warto omówić połączenia drogowe. Do najważniejszych arterii komunikacyjnych należy tzw. 
Berlinka, czyli połączenie autostradowe łączące Berlin z Królewcem przez Szczecin (Lärmer, 1975). Prace nad nim zaczęto w 1933 r., przy dużym udziale robót publicznych, które były pomysłem nazistów na niwelowanie wysokiego bezrobocia. W dniu 27 września 1936 r. Hermann Göring dokonał uroczystego otwarcia 113-kilometrowej autostrady z Berlina do Szczecina. Współcześnie jest to czteropasmowa autostrada A6 - A11, połączona z siecią autostrad europejskich. W Polsce ma długość ok. $30 \mathrm{~km}$ i łączy się z drogą ekspresową S6 i S3. Autostrada A6 (A11) została zbudowana przez Niemców jako fragment Reichsautobahn (RAB) 4A Berlin-Stettin. Do dzisiaj odgrywa ona kluczową rolę w transporcie pasażerskim i towarowym pomiędzy oboma miastami (Kluba, 2018). Biorąc pod uwagę przyszłość, ta ważna arteria komunikacyjna powinna być systematycznie modernizowana, zwłaszcza na zaniedbanych w przeszłości odcinkach jednojezdniowych.

Do omówionych powiązań komunikacyjnych należy również kwestia lotnisk (rycina 1). Podberlińskie lotnisko Brandenburg, oprócz klientów ze stolicy, przyciąga również turystów ze Szczecina. Duża liczba połączeń, nowoczesny charakter lotniska w powiązaniu z niewielką odległością od Szczecina stanowi od samego początku konkurencję dla portu lotniczego w Goleniowie czy też innych lotnisk w zachodniej Polsce. Do tego należy dodać rozwój prywatnych firm transferów lotniskowych przede wszystkim ze Szczecina i okolic, co dodatkowo popularyzuje omawiany port lotniczy. Czas brutto oraz konkurencja cenowa

Rycina 1. Połączenia transportowe w relacji Berlin - Szczecin

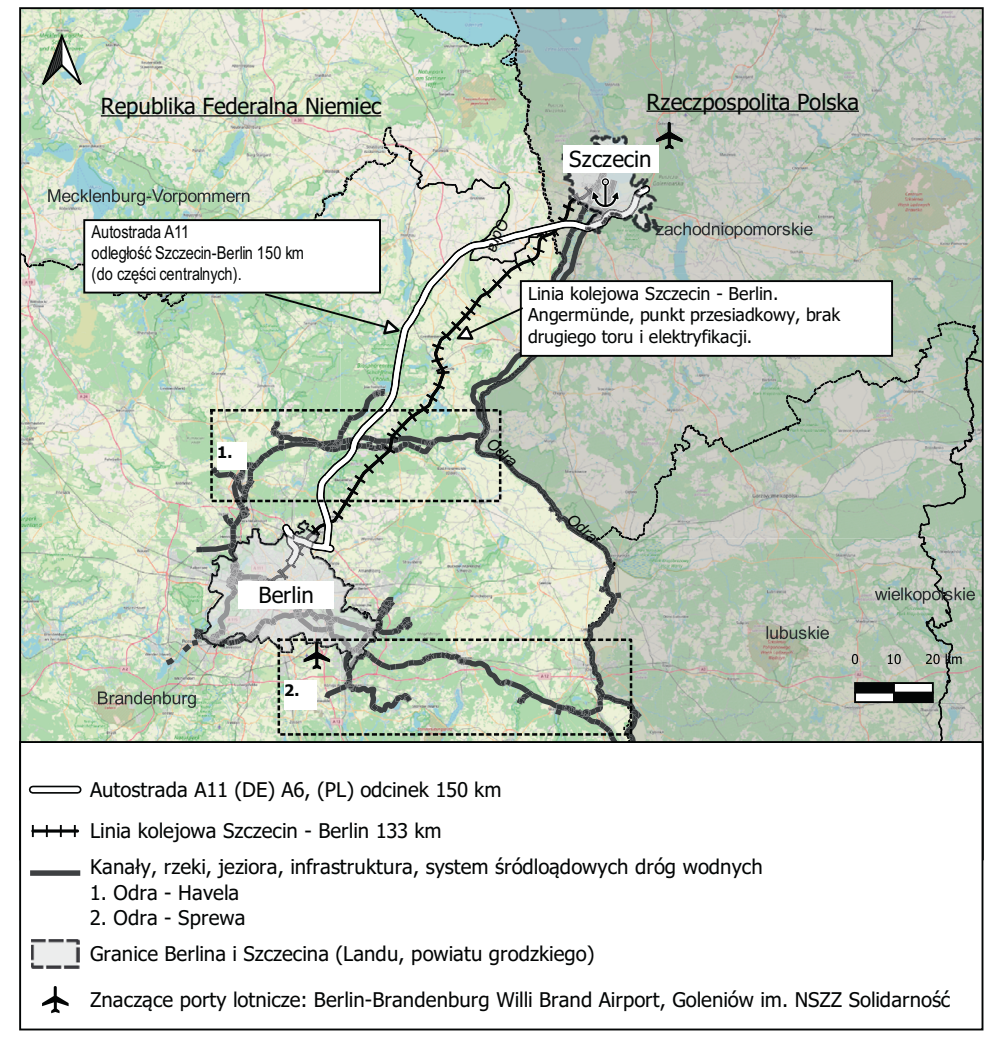

Źródło: Opracowanie własne 
globalnego huba lotniczego wymagają od władz samorządowych województwa zachodniopomorskiego znalezienia alternatyw w połączeniach lotniczych. Z drugiej strony województwo może korzystać z ogromnego potencjału transportowego wartego 7,3 mld euro globalnego portu lotniczego.

Wyrazem gospodarczych więzi obu miast jest zainicjowana w 2006 roku współpraca w ramach Partnerstwa Odry (Berlin - Stettin, Szczecin - Berlin, 2021, 10 lipca). Partnerstwo Odry to sieć kooperacyjna czterech zachodnich regionów Polski (w tym zachodniopomorskiego ze Szczecinem) oraz czterech wschodnioniemieckich krajów związkowych. Służy ono pogłębieniu powiązań politycznych, gospodarczych i infrastrukturalnych między regionami po obu stronach Odry i Nysy Łużyckiej. Głównym celem, opartej na projektach współpracy w dziedzinach: gospodarki, turystyki, transportu i infrastruktury oraz nauki i badań naukowych, platformy jest wzmacnianie sprawności gospodarczej regionów wzdłuż granicy polsko-niemieckiej (Bednarek, 2010).

Do najważniejszych dotychczasowych rezultatów współpracy zaliczyć należy stworzenie mapy Rozwój ponadregionalnej infrastruktury transportowej w obszarze Partnerstwa Odry, wzajemną promocję turystyczną regionów na rynkach pozaeuropejskich-oraz polepszenie w zakresie transgranicznego transportu kolejowego. Powyższe zadanie jest przedmiotem pracy Okrągłego Stołu Komunikacyjnego Partnerstwa Odry pod kierunkiem Związku Komunikacyjnego Berlin-Brandenburgia (VBB) (Billewicz-Wysocka, 2013).

\section{Społeczny wymiar relacji Berlina i Szczecina}

W nowej europejskiej rzeczywistości (strefa Schengen) przed Szczecinem i regionem zarysowało się wiele nowych szans, ale miasto poddane zostało stymulującemu wpływowi konkurencji wynikającej ze swobodnego przepływu osób i towarów. Miasto ma peryferyjne położenie wobec polskiej sieci osadniczej i Warszawy. Fizyczne oddalenie i niedomagania infrastrukturalne, np. linia kolejowa łącząca Szczecin z Warszawą, brak w planach budowy kolei dużych prędkości, sprawiają, że odczuwa się wyraźnie oddalenie miasta i regionu od stolicy kraju. Bliskość Berlina, jego grawitacja z kolei wywiera wpływ podobny do tego, jaki wywiera Warszawa na Mazowsze. Dużej rangi wydarzenia kulturalne i sportowe, lokalizacja działalności gospodarczych i inwestycji przyciągają od lat ludzi do kilkakrotnie większego i zamożniejszego Berlina. Do tego należy doliczyć zjawisko drenażu mniejszego miasta przez „odsysanie” talentów, inwestycji, młodzieży, a nawet mieszkańców. Należy również pamiętać, że przestrzeń pomiędzy Szczecinem a Berlinem wypełnia obszar byłego NRD, borykający się z depopulacją i starzeniem ludności.

Atrakcyjność Szczecina zmienia się z roku na rok, rośnie jakość życia w mieście, podobnie jak w miastach podobnej rangi w Polsce. Utrzymująca się konkurencyjność cenowa, zwłaszcza pod względem relacji ceny do jakości usług, niższe niż w Berlinie ceny nieruchomości mogą sprawić, że miasto będzie silniej przyciągać berlińczyków i mieszkańców wschodnich Niemiec jako alternatywne miejsce do spędzania wolnego czasu. Szczecin dla wielu Niemców jest atrakcyjnym celem weekendowych wypadów, a także dłuższych pobytów. W 2019 r. według oficjalnych statystyk GUS-u z miejsc noclegowych w samym mieście skorzystało 66 tys. Niemców. Miasto na tle kraju wyróżnia się gościnnością i przyjazną atmosferą portowego miasta, relatywnie większą otwartością na mniejszości seksualne, ludzi w różnym wieku, twórców, artystów i na swobodę wyrażania myśli i poglądów. Przez szczecińską Radę Miasta w 2020 r. przegłosowano Kartę praw osób 
$L G B T+$, co na tle wielu uchwał samorządowych o odwrotnym wydźwięku w kraju jest działaniem odważnym. Berlin dla porównania zawsze był miastem bohemy, alternatywy i swobody obyczajowej, widać to np. w obrazie Berlina w słynnym filmie Kabaret z Lizą Minnelli, czy współczesna berlińska Love Parade organizowana przez środowiska LGBT.

Drugim ważnym elementem wzajemnych relacji jest oferta kulturalna, której komponenty jako usługi, produktu wyższego rzędu, podnoszą rangę metropolitalną miasta, przyciągają osoby z zewnątrz, a jednocześnie dostarczają pośrednio impulsów rozwojowych dla gospodarki w ważnej we współczesnym świecie sferze kreatywności. Kreatywność, bogactwo oferty kulturalnej, może sprawić, że na ulicach miasta zobaczymy więcej turystów z Berlina, a w Berlinie ze Szczecina. Berlin od lat jest zaliczany bezapelacyjnie do wiodących w Europie ośrodków turystyki kulturowej (np. oferta Museumsinsel, a także liczne opery i teatry) (Wedel, 2002). Do tego należy dodać Berlin jako cel dla innego rodzaju aktywności turystycznych (np. szlaki rowerowe EuroVelo, Berliner Mauerweg) z racji wysokiego poziomu zagospodarowania turystycznego oraz dogodnej dostępności komunikacyjnej ze Szczecina i okolic. Szczecin stara się sukcesywnie poszerzać swoją ofertę kulturalną, atrakcyjną również dla turysty zagranicznego, czego wyrazem są inwestycje w infrastrukturę sportową, społeczną i kulturalną oraz postępująca estetyzacja miasta, zwłaszcza w obszarze bulwarów nadodrzańskich. Niektóre spośród inwestycji nawiązują do przedwojennych tradycji. W miejscu zniszczonego w nalotach Konzerthausu w 2014 r. wybudowano awangardową filharmonię. Budynek został nagrodzony m.in. nagrodą Unii Europejskiej im. Miesa van der Rohe dla współczesnej architektury. To raz pierwszy nagrodzony budynek z Polski (fotografia 3).

Fotografia 3. Gamach szczecińskiej Filharmonii im. Mieczysława Karłowicza. Projekt studio Barozzi Veiga

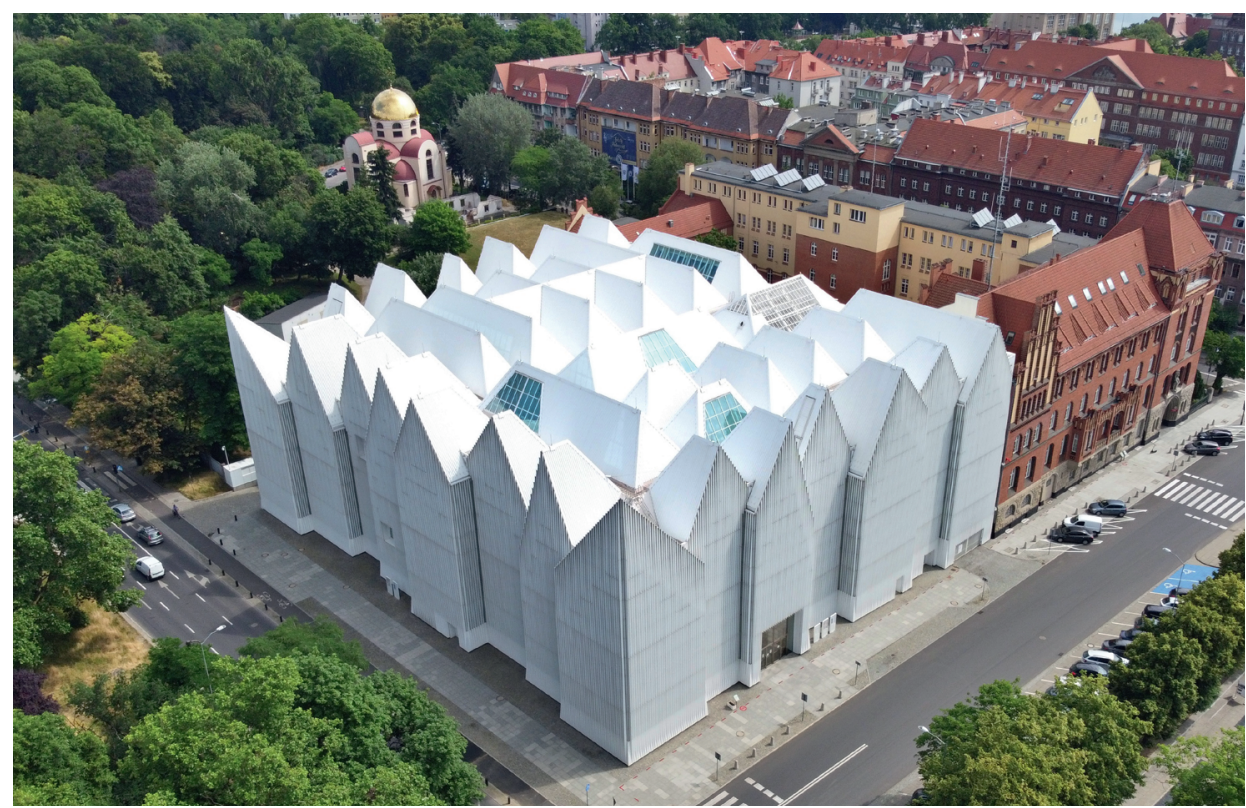

Źródło: Autorstwa Kapitel - Praca własna, CC BY-SA 4.0, https://commons.wikimedia.org/w/index.php?curid $=107532730$ 
Do najważniejszych cyklicznych imprez masowych i z zakresu kultury wyższej o międzynarodowym znaczeniu w Szczecinie zaliczyć należy:

- Dni Morza,

- Międzynarodowy Festiwal Sztucznych Ogni Pyromagic,

- regaty The Tall Ships Races,

- Międzynarodowy Konkurs Baletowy „Złote Pointy”,

- Szczecin European Film Festival,

- Szczecin Music Fest,

- Kontrapunkt, Przegląd Teatrów Małych Form

- Międzynarodowy Festiwal Muzyczny „Sacrum Non Profanum”.

Szczecin i okolice stanowią cel krótkich turystycznych wyjazdów wypoczynkowych dla mieszkańców Berlina. Atrakcyjność Szczecina wynika głównie z konkurencyjnego $\mathrm{w}$ porównaniu $\mathrm{z}$ rynkiem niemieckim poziomu cen - w mieście zaobserwować można zorganizowane grupy turystów i podróżujących indywidualnie, dla których celem przyjazdu jest turystyka zakupowa i usługowa - oparta na usługach stomatologicznych, kosmetycznych, wellness \& spa, chirurgii plastycznej i fizjoterapii.

Wielu berlińczyków pochodzi ze Szczecina (brakuje dokładnych danych), Berlin od lat stanowi atrakcyjne miejsce do zamieszkania i pracy dla wielu Polaków. W Berlinie mieszka obecnie 124921 osób o polskim pochodzeniu (Lemańczyk, 2021). Stolica Niemiec jest także miejscem życia dla 3-4 tys. osób bezdomnych z Polski (Wanat, 2018). Do tego należy doliczyć kilka tysięcy dojeżdżających do szkół i pracy (Szczepański, 2016). Ważnym elementem relacji społecznych obu miast jest przy tym tworzenie atrakcyjnych nowych perspektyw zawodowych miejsc pracy (Madejski, 2021, 3 lipca). Do czynników przyciągających polskich pracowników do Berlina i jego okolic zaliczyć możemy:

- atrakcyjne zarobki i warunki zatrudnienia,

- dużą liczbę firm i miejsc pracy,

- niewielką odległość,

- dobre skomunikowanie z obszarami Polski.

Szczecin jest współcześnie miejscem pracy dla ok. 2,5 tys. Niemców. Niemcy w Szczecinie pracują w branży budowlanej, porcie szczecińskim oraz centrach BPO. W mieście od 1997 r. stacjonują także żołnierze niemieccy wraz z rodzinami w ramach Wielonarodowego Korpusu Północno-Wschodniego NATO (Niemcy emigrują..., 2021, 23 lipca).

Analizując rynki pracy po obu stronach granicy, można wysnuć wnioski, że oba miasta wykazują wzajemne odziaływanie, z oczywistą przewagą chłonnego obszaru metropolitalnego Berlina. Zarówno osoby o wysokich kwalifikacjach zawodowych, jak i o niższych kwalifikacjach, pochodzące $\mathrm{z}$ terenów przygranicznych, mogą znaleźć atrakcyjne zatrudnienie po stronie niemieckiej. Szczecin staje się przy tym atrakcyjny również dla mieszkańców wschodniej części landu Meklemburgia-Pomorze Przednie z uwagi na znaczne oddalenie jednostek administracyjnych (Landkreiss) od stolicy Schwerina i ambiwalentny stosunek mieszkańców landu do Berlina. Od kilku lat obserwowane jest też zasiedlanie przygranicznych miejscowości przez mieszkańców pochodzących z Obszaru Metropolitalnego Szczecina. Praktyczny brak granic, relatywnie dobry dojazd i konkurencyjne ceny nieruchomości oraz korzyści życia dwusystemowego po stronie niemieckiej przyciągają nowych mieszkańców pochodzenia polskiego. Korzyści dwusystemowe polegają na relacji siły nabywczej polskich i niemieckich płac i cen oraz transferów socjalnych, np. emerytur, rent, zasiłku rodzinnego tzw. kindergeld, a także, co istotne, dwujęzyczności 
(Rudewicz, 2017). W wyniku procesu poszerzania się obszaru funkcjonalnego Szczecina poza granice państwowe w 2012 r. powstała z inicjatywy samorządowców regionów Meklemburgii i Pomorza Przedniego, Brandenburgii, województwa zachodniopomorskiego oraz Stowarzyszenia Gmin Polskich Euroregionu Pomerania koncepcja Transgranicznego Rozwoju Metropolitalnego Szczecina (TRMSZ). Projekt został uznany za jeden z pięciu modelowych projektów współpracy polsko-niemieckiej. Inicjatywa z biegiem lat straciła nieco impet. W 2021 r., za sprawą pandemii, która unaoczniła obu stronom skutki zamknięcia granic na pograniczu polsko-niemieckim, w Landtagu Meklemburgii-Pomorza Przedniego odbyło się posiedzenie dotyczące metropolii szczecińskiej. Premier Landu Manuela Schwesig, sekretarz stanu ds. Pomorza Przedniego Patrick Dahlemann (oboje z SPD) oraz liderzy współrządzącej CDU złożyli projekt uchwały zakładającej zintensyfikowanie współpracy z polskimi partnerami w ramach Szczecińskiego Obszaru Metropolitalnego. Warto podkreślić, że jedną z wielu korzyści rozwoju TRMSZ w odniesieniu do analizowanych relacji Berlin - Szczecin jest umocnienie się tego obszaru i uatrakcyjnienie wobec oddziaływania gospodarczego Berlina oraz nadanie większej rangi i przewagi negocjacyjnej Szczecinowi, a także terenom po stronie niemieckiej (Madejski, 2019).

\section{Podsumowanie}

Informacje i analizy porównawcze zawarte $\mathrm{w}$ artykule stanowią wstępny rekonesans złożonych relacji i problemów badawczych oddziaływania na siebie Berlina i Szczecina, miast, które łączyły niegdyś więzi wspólnego systemu osadniczego i powiązania funkcjonalne. Członkostwo obu krajów w UE, a także w strefie Schengen staje się powoli katalizatorem wzajemnej współpracy i odbudowy relacji.

Istniejący potencjał współpracy nie jest obecnie w pełni wykorzystywany. Uwarunkowane jest to stopniem rozwoju łączącej miasta infrastruktury transportowej, zwłaszcza kolei posiadającej przewagę szybkości nad transportem drogowym, a także dróg wodnych - niskoemisyjnego i atrakcyjnego turystycznie oraz gospodarczo środka transportu. Obszar Metropolitalny Szczecina i samo miasto ma szansę zająć należne im miejsce na mapie współpracy społeczno-gospodarczej obszarów transgranicznych. Nadgraniczne położenie stwarza możliwość uzyskania przewag konkurencyjnych dla miasta i regionu. Wyobrażenie takiej współpracy dla wielu osób w Polsce może być kontrowersyjne, wynikać z uprzedzeń i poczucia zagrożenia tożsamości narodowej, nie tylko wpływem kultury niemieckiej, ale multikulturowością stolicy Niemiec. Warto ten punkt widzenia zastąpić bardziej pragmatyczną wizją silnego ekonomicznie, połączonego infrastrukturalnie i bardziej konkurencyjnego transgranicznego obszaru metropolitalnego, którym ma szansę zostać Szczecin. Obszaru czerpiącego inspiracje dla rozwoju z wzajemnych inicjatyw i współpracy na polu gospodarczym oraz kulturowym. Bliskość Berlina dla Szczecina miasta, regionu o randze silnego obszaru metropolitalnego, niesie za sobą dyfuzję informacji, przejawiającą się przejmowaniem wzorców zachowań, stylu życia, transferu wiedzy. W miejskiej debacie publicznej dotyczącej rozwiązań komunikacyjnych, ekologicznych, poziomu rozwoju kultury, kapitału społecznego mieszkańców, co wynika z obserwacji autorów, Berlin często stawiany jest jako wzór i punkt odniesienia. Omawiany w artykule proces konwergencji obu ośrodków przebiega relatywnie wolno, w kolejnych badaniach warto pochylić się nad problemem przyspieszenia tego procesu, analizy szans i zagrożeń wynikających z rozwoju Berlina i jego większej dostępności z okolic Szczecina, rozwoju oferty kulturalnej 
i turystycznej, poprawy warunków życia w Szczecinie, otwartości i tolerancji jego mieszkańców wobec obcokrajowców, a także kwestii tożsamości mieszkańców Szczecina.

\section{Literatura}

References

Bednarek, R. (2010). Superregion polsko-niemiecki jako próba reaktywacji planu Stolpego-Willersa. T. 2, Białystok: Oficyna Wydawnicza Politechniki Białostockiej.

Berlin - Stettin, Szczecin - Berlin. (2021, 10 lipca). Pozyskano z: http://www.oder-partnerschaft.eu/files/ file/Berlin-Stettin.pdf

Białecki, T. (1992). Historia Szczecina. Wrocław: Zakład Narodowy im. Ossolińskich.

Billewicz-Wysocka, I. (2013). Okragły Stót - Partnerstwo Odry (pol.). Urząd Marszałkowski Województwa Lubuskiego.

Chojnicki, Z. (1965). Zastosowanie modeli grawitacji i potencjału w badaniach przestrzenno-ekonomicznych. Warszawa: PWN.

Dziewoński, K. (1967). Baza ekonomiczna i struktura funkcjonalna miast. Prace Geograficzne, Instytut Geografii PAN, 63.

Ferrix. (2021, 25 czerwca). Historia i przewozy na linii Berlin - Szczecin. Pozyskano z: https://kolej.mkm. szczecin.pl/encyklopedia/berlin_szczecin

Frymus, M. (2021, 3 lipca). Co łączy Szczecin i Berlin?. Pozyskano z: https://radioszczecin.pl/4,384298,c o-laczy-szczecin-i-berlin-mozna-bylo-dowiedziec.

Grzeszczak, J. (1999). Bieguny wzrostu a formy przestrzeni spolaryzowanej. Prace Geograficzne, Instytut Geografii PAN, 173.

Hahn, P. (2007). W 70. rocznicę śmierci rzeźbiarza Karla Ludwiga Manzela. Märkische Allgemeine, 15 lutego.

Jesswein, R. (2019; 2021, 13 lipca). Enklawa. Jak Sowieci wywozili łupy przez port w Szczecinie. Pozyskano z: https://szczecin.wyborcza.pl/szczecin/7,150424,24701572,enklawa-jak-sowieci-wywozililupy-przez-port-w-szczecinie.html

Kluba, A. (2018; 2021, 13 lipca). Zachodniopomorskie: Wygodniej nad morze - nowa berlinka DW142 stuży kierowcom. Pozyskano z: https://conadrogach.pl/informacje/zachodniopomorskie-wygodniej-nad-morze-nowa-berlinka-dw142-sluzy-kierowcom.html

Kotowska, I. (2011). Możliwości aktywizacji przewozów drogą wodną Szczecin - Berlin. Logistyka, 6.

Kozłowski, K., Krzywicki, S. (1988). Historyczna droga do polskiego Szczecina. Szczecin: Krajowa Agencja Wydawnicza.

Lärmer, K. (1975). Autobahnbau in Deutschland 1933 bis 1945. Berlin.

Lejman, T. (2020; 2021, 3 lipca). „Następna stacja: Berlin Szczeciński”. Narodziny i upadek wielkiego dworca. Pozyskano z: https://www.polsatnews.pl/wiadomosc/2020-02-22/nastepna-stacja-berlin-szczecinski -narodziny-i-upadek-wielkiego-dworca/

Lemańczyk, B. (2021, 11 lipca). Polacy najliczniejsza grupą obcokrajowców w Berlinie. Pozyskano z: https:// www.bankier.pl/wiadomosc/Polacy-najliczniejsza-grupa-obcokrajowcow-w-Berlinie-8131740.html

Łysakowska, A. (2015; 2017, 6 lipca). Jak Stettin stat się Szczecinem. Pozyskano z: Histmag.org

Madejski, M. (2018; 2021, 11 lipca). Powstaje największa „winda” dla statków w Europie. Nikt nie skorzysta bardziej niż Polacy. Pozyskano z: https://finanse.wp.pl/powstaje-najwieksza-winda-dla-statkow-w-europie-n ikt-nie-skorzysta-bardziej-niz-polacy-6311158156174977a

Madejski, M. (2019; 2021, 11 lipca). Niemcy chcą zrobić ze Szczecina aglomerację.,,Bo Berlin nas ignoruje”. Pozyskano z: https://www.money.pl/gospodarka /niemcy-chca-zrobic-ze-szczecina-aglomeracje-bo-berl in-nas-ignoruje-6407803313514113a.html

Madejski, M. (2021, 3 lipca). Firmy z Berlina poszukuja pracowników w Szczecinie. Sprawdziliśmy, czy opłaca się dojeżdzać. Pozyskano z: https://finanse.wp.pl/firmy-z-berlina-poszukuja-pracownikoww-szczecinie-sprawdzilismy-czy-oplaca-sie-dojezdzac-6448491046565505a 
Mąka, H. (1978). Szczecin. Wczoraj, dziś, jutro. Warszawa: Wydawnictwo Interpress.

Miasta partnerskie Miasta Szczecin. (2021, 2 czerwca). Pozyskano z: http://bip.um.szczecin.pl/chapter_11296.asp

Niemcy emigruja do Szczecina. Zachodniopomorskie jest dla nich atrakcyjne finansowo. (2021, 23 lipca). Pozyskano z: https://gs24.pl/niemcy-emigruja-d o-szczecina-zachodniopomorskie-jest-dla-nich-atrakcyjne-finansowo/ar/5385122

Nowosielska, E. (1992). Teoria Christallera - prawda i mity (w sprawie nieporozumień pojęciowych). Dokumentacja Geograficzna, 3, IGIZ PAN, Warszawa.

Rudewicz, J. (2017). Przedsiębiorczość i motywy osiedlania się Polaków w niemieckiej części obszaru funkcjonalnego miasta Szczecin. Studium przypadku miejscowości Löcknitz. Przedsiębiorczość Edukacja [Entrepreneurship - Education], 13, 87-105. https://doi.org/10.24917/20833296.13.7

Rudnicki, M. (2010). Hitler, Honorowy Obywatel Szczecina. Głos Szczeciński, 31 lipca.

Strohmeyer, K. (2000). James Hobrecht. (1825-1902) und die Modernisierung der Stadt. Verlag für Berlin-Brandenburg.

Starcken, G. (2016). Schifffahrt über den Berg. Von Geschichte und Entwicklung des Oder-Spree-Kanals. Norderstedt.

Strączyński, M. (2019). Pojezierze Meklemburskie. Przewodnik dla wodniaków, Szczecin: Zapol sp.j.

Szczecin Music Fest. (2021, 2 lipca). Pozyskano z: https://koncerty.com/pl/32/szczecin_music_fest

Szczepański, W. (2016; 2021, 12 lipca). ,Złośliwie mówimy, że Berlin jest nasza stolicą. To w Szczecinie urodziło się najwięcej nowych... berlińczyków. Pozyskano z: https://natemat.pl/192843,zaskakujacy-ranking-niemieckiej-gazety-wiemy-z-jakiego-polskiego-miasta-pochodzi-najwiecej-berlinczykow

Śląski, K. (red.). (1960). Pomorze Zachodnie. Nasza ziemia ojczysta, Poznań: Wydawnictwo Poznańskie. Śleszyński, P. (2009). Ocena powiązań gospodarczych i kapitałowych miedzy miastami. W: K. Saganowski, M. Zagrzejewska-Fiedorowicz, P. Zuber, Ekspertyzy do Koncepcji przestrzennego zagospodarowania kraju 2008-2033, t. I, Warszawa: Ministerstwo Rozwoju Regionalnego.

Uhlemann, H.J. (1994). Berlin und die märkischen Wasserstraßen. DSV/Hamburg: Busse-Seewald, Herford.

Wanat, E. (2018; 2021, 3 lipca). Tysiace bezdomnych Polaków na ulicach Berlina. Ambasada chce namówić 20 do powrotu. Pozyskano z: https://oko.press/tysiace-bezdomnych-polakow-na-ulicach-berlina-ambasada-chce-namowic-20-do-powrotul

Wedel, C. (red.). (2002). Die Neue Museumsinsel. Der Mythos. Der Plan. Die Vision. Berlin: Nicolaische Verlagsbuchhandlung.

Widzyk, A. (2020; 2021, 12 września). Berlin policzył swoich bezdomnych. Zaskakujący wynik. Pozyskano z: https://www.d w.com/pl/berlin-policzy\%C5\%82-swoich-bezdomnych-zaskakuj\%C4\%85cy-wynik/a-52296573

Wojtkun, P. (2020). Wielka szczecińska przestrzeń. Geneza i tło. Szczecin: Wydawnictwo Uczelniane Zachodniopomorskiego Uniwersytetu Technologicznego w Szczecinie.

Wright, P. (2009). Żelazna Kurtyna. Poznań: Świat Książki.

Zbroja, Z. (2021, 30 sierpnia). Wassertourismus in Polen - stettiner haff + untere oder + Ostsee. Pozyskano z: http://oderverein.de/w pcontent/uploads/08_HerrSbroja.pdf

Jacek Rudewicz, dr inż., adiunkt. Uniwersytet Szczeciński, Instytut Gospodarki Przestrzennej i Geografii Społeczno-Ekonomicznej, Wydział Ekonomii Finansów i Zarządzania. Ukończył kierunek geografia ze specjalnością geografia społeczno-ekonomiczna, kierunek zarządzanie i marketing oraz ekonomia. W pracy naukowej zajmuje się m.in.: studiami miejskimi, rozwojem zrównoważonym, rozwojem regionalnym, geografią społeczno-ekonomiczną.

Jacek Rudewicz, PhD, Research Assistant. University of Szczecin, Institute of Economic and Geographical Economics, Department of Financial Economics and Management. A Geography graduate, with specialisation in social and economic geography, management and marketing, and economics. In his research work, he is interested in, among other things: local studies, peer development, regional development, social and economic geography.

ORCID: https://orcid.org/0000-0002-2659-4754 


\section{Adres/Address:}

Uniwersytet Szczeciński

Instytut Gospodarki Przestrzennej i Geografii Społeczno-Ekonomicznej

Wydział Ekonomii Finansów i Zarządzania

ul. Mickiewicza 64

71-101 Szczecin, Poland

e-mail: jacek.rudewicz@usz.edu.pl

Krzysztof Sala, dr, adiunkt. Uniwersytet Pedagogiczny im. Komisji Edukacji Narodowej, Instytut Politologii. Absolwent: międzynarodowych stosunków gospodarczych (specjalność: studia europejskie) na Uniwersytecie Ekonomicznym w Krakowie (studia magisterskie) zakończonych dyplomem na podstawie pracy Realizacja polityki ekorozwoju w krajach skandynawskich, podyplomowych studiów w zakresie zarządzania jakością i ochroną środowiska w Wyższej Szkole Zarządzania i Bankowości w Krakowie oraz Kolegium Zarządzania i Finansów Szkoły Głównej Handlowej w Warszawie, gdzie uzyskał tytuł doktora nauk ekonomicznych na podstawie rozprawy Nowe rodzaje turystyki jako przejaw postmodernizmu zachowań konsumenckich w Polsce. Ma wieloletnie doświadczenie w praktyce gospodarczej na różnych stanowiskach zawodowych, w tym stanowiskach menadżerskich. Zdobył doświadczenie w pracy naukowo-dydaktycznej na uczelniach publicznych i prywatnych. Uczestniczył jako trener w szkoleniach finansowanych z UE w ramach programu Kapitał Ludzki z zakresu dotyczącego szeroko rozumianej turystyki i zarządzania. Do głównych obszarów zainteresowań zalicza politykę gospodarczą i turystyczną Polski i Unii Europejskiej, przedsiębiorczość w sektorze małych i średnich firm oraz zarządzanie strategiczne.

Krzysztof Sala, $\mathrm{PhD}$, Research Assistant. Pedagogical University of Krakow, Institute of Political Science. A graduate of International Economic Relations (specialization European Studies) at the Cracow University of Economics (master's degree) completed diploma on the basis of the work Implementation of the policy of sustainable development in the Nordic countries, post-graduate studies in the field of quality management and environmental protection School of Management and Banking in Krakow and the College of Management and Finance School of Economics in Warsaw, leading to a doctoral degree in economic sciences for the thesis New types of tourism as a manifestation of postmodern consumer behavior in Poland. Many years of experience in business practice in various positions unions, including managerial positions. Experience in scientific and teaching work gained public and private. Participation as a coach in training funded by the EU under the Human Capital the scope for the wider tourism and management. The main areas of interest include economic policy and tourism Polish and European Union, entrepreneurship in small and medium-sized businesses, and strategic management.

ORCID: https://orcid.org/0000-0002-7614-9309

\section{Adres/Address:}

Uniwersytet Pedagogiczny im. Komisji Edukacji Narodowej w Krakowie

Instytut Prawa i Ekonomii

Katedra Przedsiębiorczości i Innowacji Społecznych

ul. Podchorążych 2

30-084 Kraków, Poland

e-mail: krzysztof.sala@up.krakow.pl 